\title{
Genetic parameters and performance of sugarcane families under cold stress in the South of Brazil
}

\author{
Mario Alvaro Aloisio Verissimo(1), Ricardo Augusto de Oliveira(1), \\ Sérgio Delmar dos Anjos e Silva(2), Edelclaiton Daros ${ }^{(1)}$ and Adílson Härter(2)
}

\begin{abstract}
(1)Universidade Federal do Paraná, Rua dos Funcionários, № 1.540, CEP 80035-050 Curitiba, PR, Brazil. E-mail: maaverissimo@gmail.com, rico@ufpr.br, ededaros@ufpr.br (2)Embrapa Clima Temperado, Caixa Postal 403, CEP 96010-971 Pelotas, RS, Brazil. E-mail: sergio.anjos@embrapa.br, adilsonharter@gmail.com
\end{abstract}

Abstract - The objective of this work was to estimate the genetic parameters for the performance prediction of sugarcane (Saccharum spp.) families under natural cold stress, in Southern Brazil, and to identify the best combinations of parents aiming at the selection for tolerance to cold. Fifty-three full-sib families were evaluated in an incomplete block design, with five replicates per family, in the municipality of Pelotas, in the state of Rio Grande do Sul, Brazil. Harvest occurred in August 2013, nine months after planting and after cold spells with negative temperatures down to $-2.2^{\circ} \mathrm{C}$. Statistical analyses, performed with the mixed model methodology, detected significant differences among families. Heritability estimates among progeny means were higher than those of individual heritability. Estimates of genetic progress for the traits megagrams of stalks per hectare, megagrams of brix per hectare, and number of stalks indicated gains of 93.8, 91.0, and $53.3 \%$, respectively. A set of eight promising families that combine high estimates for yield and cold stress tolerance was obtained.

Index terms: Saccharum, cold tolerance, plant breeding, selection.

\section{Parâmetros genéticos e desempenho de famílias de cana-de-açúcar sob estresse por frio no Sul do Brasil}

\begin{abstract}
Resumo - O objetivo deste trabalho foi estimar os parâmetros genéticos para prever o desempenho de famílias de cana-de-açúcar (Saccharum spp.) sob condições naturais de estresse por frio, no Sul do Brasil, e identificar as melhores combinações de genitores para a seleção quanto à tolerância ao frio. Cinquenta e três famílias de irmãos completos foram avaliadas em delineamento de blocos incompletos, com cinco repetições por família, no Município de Pelotas, RS. A colheita foi realizada em agosto de 2013, nove meses após o plantio e após eventos de frio com temperatura negativa que chegou a $-2,2^{\circ} \mathrm{C}$. As análises estatísticas, realizadas por meio da metodologia de modelos mistos, detectaram diferenças significativas entre as famílias. As estimativas de herdabilidade em nível de família foram maiores do que as de herdabilidade em nível de indivíduo. As estimativas quanto ao progresso genético para os caracteres megagramas de cana por hectare, megagramas de brix por hectare e número de talos indicaram ganhos de $93,8,91,0$ e 53,3\%, respectivamente. Obteve-se um conjunto de oito famílias potenciais que combinam elevadas estimativas de rendimento e tolerância ao estresse por frio.
\end{abstract}

Termos para indexação: Saccharum, tolerância ao frio, melhoramento vegetal, seleção.

\section{Introduction}

Sugarcane (Saccharum spp. - hybrids) is considered a cold-sensitive crop (Hale et al., 2016; Silva, 2017) and is cultivated in tropical and subtropical areas where frost is not a common phenomenon. However, in case of freezing, harvest losses and sucrose accumulation capacity in the stalks may be reduced. According to Hale et al. (2016), in approximately $25 \%$ of the sugarcane-producing countries, conventional sugarcane is exposed to damaging frosts. In Brazil alone, the sugarcane acreage exposed to potential cold damage can reach 1.2 million hectares, mainly in the Centre-South region (Acompanhamento..., 2016; FAO, 2017).

The nature and extent of crop damage depends on the intensity and duration of the frost event (Legendre et al., 2007; Hale et al., 2016). The weather after 
freezing also affects the deterioration rate. Critical temperatures for frost damage in sugarcane have been reported, showing that a slight damage to terminal buds occurs between 0.0 and $-2.2^{\circ} \mathrm{C}$, and that the apical meristem and auxiliary buds are killed between -2.8 and $-3.9^{\circ} \mathrm{C}$ (Edmé \& Glaz, 2013; Hale et al., 2016). When temperatures reach $-5.6^{\circ} \mathrm{C}$, the stalks are susceptible to cracking, and severe deterioration is observed within 1-2 weeks for most genotypes (Hale et al., 2016).

The call for studies on varietal resistance of many agricultural crops to face abiotic stresses has been intensified in recent years. In Australia, Canada, USA, and South Africa (Van Heerden et al., 2009; Edmé \& Glaz, 2013; Friesen et al., 2014; Hale et al., 2016; Silva, 2017), tests are performed to evaluate cold and frost tolerance of promising sugarcane cultivars and clones. Sun et al. (2017) claimed that low temperature is one of the main factors limiting sugarcane growth, yield, and quality.

In Brazil, in evaluations of sugarcane cultivars used in the 1970s, Cesnik et al. (1978) confirmed the tolerance to cold of the cultivar NA56-62. However, further studies are required to observe the more frequent extremely cold weather effects on sugarcane-growing (Sun et al., 2017). A strategy for sugarcane breeding for tolerance to cold or frost is the selection of families under this kind of environmental stress.

Family selection strategy proved to be essential in sugarcane breeding (Barbosa et al., 2005; Atkin et al., 2009; Stringer et al., 2011), and it can be adopted if the heritability of the target selection traits is low, as is the case for yield-related traits (Resende \& Barbosa, 2006). The components of variance and genetic parameters of the yield-related traits in the sugarcane family trials have been studied in several breeding programs worldwide (Kimbeng \& Cox, 2003; Barbosa et al., 2005; Resende \& Barbosa, 2006; Oliveira et al., 2011, 2016; Stringer et al., 2011). However, such studies associated with the soil and climate conditions of Brazil are still necessary.

The objective of this work was to estimate the genetic parameters for the performance prediction of sugarcane families under natural cold stress in southern Brazil, and identify the best combinations of parents for the selection for cold tolerance.

\section{Materials and Methods}

Pesq. agropec. bras., Brasília, v.53, n.5, p.583-592, May 2018 DOI: 10.1590/S0100-204X2018000500007
Botanical seed of 53 full-sib sugarcane families (progenies) were obtained from a biparental cross at the crossing station of Serra do Ouro, of Universidade Federal de Alagoas (Ufal), in the municipality of Murici, in the state of Alagoas, Brazil, in 2012. The caryopses were sown on July 31, 2012, and maintained in a greenhouse of Universidade Federal do Paraná (UFPR), at the experimental station in the municiapality of Paranavaí, in the state of Paraná, Brazil. Three months after sowing, in the beginning of December 2012, the seedlings were transplanted to the field at the experimental station of Embrapa Clima Temperado, in the municipality of Pelotas $\left(31^{\circ} 41^{\prime} 11^{\prime \prime} \mathrm{S}\right.$, $52^{\circ} 25^{\prime} 55^{\prime \prime} \mathrm{W}$, at $50 \mathrm{~m}$ altitude), in the state of Rio Grande do Sul, Brazil, forming the T1 population.

The soil of the experimental station was classified as a Argissolo Vermelho-Amarelo, according to the Brazilian soil classification system (Santos et al., 2013). The regional climate, according to the KöppenGeiger's classification, is Cfa, humid subtropical, with no defined dry seasons and hot summers. Temperature data were collected in situ, from the mid-canopy of the plants, with a data logger model RHT10 (Extech USB, Boston, MA, USA), as well as in the meteorological station at Embrapa Clima Temperado, from April to August 2013. Mean temperatures in the experimental areas varied from 12.4 to $19.0^{\circ} \mathrm{C}$ (Table 1); the highest temperature of the study period was $33.7^{\circ} \mathrm{C}$ in April, and the lowest one was $-2.2^{\circ} \mathrm{C}$, in July $(7 / 24 / 2013)$.

Three months before planting, fertilization and liming were applied according to soil analysis. The soil was tilled by plowing once and disking twice; then, ridges were formed (in the form of beds, with $30 \mathrm{~cm}$ height, and $1.40 \mathrm{~m}$ center-to-center distance). Before planting, $60 \mathrm{~kg} \mathrm{ha}^{-1} \mathrm{~N}, 120 \mathrm{~kg} \mathrm{ha}^{-1} \mathrm{P}_{2} \mathrm{O}_{5}$, and $120 \mathrm{~kg} \mathrm{ha}^{-1} \mathrm{~K}_{2} \mathrm{O}$ were applied and incorporated to the ridges. In February, a side dressing of $100 \mathrm{~kg} \mathrm{ha}^{-1}$ of chlorinated urea was applied. The cultural treatments after planting were applied as suggested by Zambon \& Daros (2009).

The experiment was arranged in incomplete blocks, and the treatments consisted of 53 full-sib families. Each plot consisted of one $10 \mathrm{~m}$ row, with $1.4 \mathrm{~m}$ spacing between rows, and $0.5 \mathrm{~m}$ between plants, totaling 20 plants per plot, and 5 replicates.

Families were evaluated at harvest, 12 months after planting, at the end of August, 2013. Traits 
evaluated for each plant (sugarcane clump) were: number of stalks per clump (NSC), by counting the millable stalks per clump; mean stalk height ( $\mathrm{SH})$, measured with a metric ruler $(\mathrm{cm})$ from the ground to the insertion point of the $3^{\text {rd }}$ leaf; mean stalk diameter (SD), measured with a caliper at the lower third of the stalk (mm); total soluble solids or ${ }^{\circ}$ brix (BRIX), measured with a digital refractometer in the mid-third of the stalk; survival score of the apical bud (ABS) and survival score of the top leaves (TLS). In August 2013, approximately 30 days after the first frosts, scores were assigned once according to the survival degree, where: 1, dead apical bud and cold-induced necrotic lesion larger than five centimeters $(>5.0 \mathrm{~cm})$ below the apical bud, and dead or without lateral sprouting, or canopy with completely frost-injured (burned) leaves, with severely damaged leaves, and less than $20 \%$ of the canopy with green leaves; 2, dead apical bud with a 2.0 to $5.0 \mathrm{~cm}$ long lesion under the bud, and visible lateral bud, or canopy with completely damaged leaves, and 20 to $40 \%$ of the canopy with green leaves at the time of evaluation; 3 , dead apical bud, with 0.5 to $2.0 \mathrm{~cm}$ long lesion below the bud, abundant lateral sprouting, or canopy with a few completely damaged leaves, and 40 to $60 \%$ of the canopy with green leaves; 4, apical bud with small lesion $(<0.5 \mathrm{~cm})$ and presence of live tissue with growth resumption along the central axis of the stalk, without visible lateral buds, or canopy with some leaves damaged from the center to the tips, and 60 to $80 \%$ of the canopy with green leaves; and 5, live bud, with no visible lesion and no lateral sprouting; or green canopy, with only some damaged leaf tips, and green color of more than $80 \%$ of the canopy.

Survival scores were applied to each plant individually (sugarcane clump), and one stalk per clump. The results are presented as the mean genotypic value (Vgf) of the families.

Stalk yield was estimated in megagrams of stalks per hectare (MSH), according to a methodology proposed by Landell $\&$ Silva (2004), considering a stalk density of 1.0, where: $\mathrm{MSH}=\left(\mathrm{d}^{2} \times \mathrm{C} \times \mathrm{h} \times 0.007854\right) / \mathrm{S}$, in which: $\mathrm{d}$ is the stalk diameter $(\mathrm{cm})$; $\mathrm{C}$ is the number of tillers per meter in the plant row; $h$ is the mean stalk height $(\mathrm{cm})$; and $\mathrm{S}$ is the spacing between plant rows $(1.4 \mathrm{~m})$. Finally, the trait megagrams of brix per hectare (MBH) was computed as the product of Brix by MSH, divided by 100 .

Data were analyzed with mixed models, using the software Selegen REML/Blup (Resende, 2016). The components of variance and genetic parameters were estimated by the maximum restricted likelihood (REML). The statistical model according to Resende (2007) was associated with the evaluation of full-sib families obtained from an unbalanced diallel cross, unrelated parents, in an incomplete block design, as $\mathrm{y}=\mathrm{Xr}+\mathrm{Za}+\mathrm{Wp}+\mathrm{Sf}+\mathrm{Tb}+\mathrm{e}$, in which: $\mathrm{y}, \mathrm{r}$, $\mathrm{a}, \mathrm{p}, \mathrm{f}, \mathrm{b}$, and $\mathrm{e}$, are data vectors of the replicate effects, assumed as fixed, added to the general mean; individual additive genetic effects are assumed as random; plot effects are assumed as random; genetic effects of dominance are associated with full-sib families and assumed as random; effects of incomplete blocks (random); effects of errors or residues are also assumed as random; and X, Z, W, S, and $\mathrm{T}$ represent the incidence matrices for the effects of $r, a, p, f$, and $b$, respectively.

The genetic gains expected from selection were estimated using a selection pressure of $10 \%$, by the expression GS $=h^{2} \times D S$, in which: $h^{2}$ is the heritability coefficient between means of full-sib families; and DS is the selection differential. The genetic gain

Table 1. Monthly distribution of minimum air temperatures in percentage of days (\%) and minimum, absolute maximum, and monthly mean temperatures, measured in situ from April to August 2013, in the municipality of Pelotas, in the state of Rio Grande do Sul, Brazil.

\begin{tabular}{|c|c|c|c|c|c|c|c|c|c|c|}
\hline \multirow[t]{2}{*}{ Month } & \multicolumn{7}{|c|}{ Minimum temperature $\left({ }^{\circ} \mathrm{C}\right)$ in percentage of days $(\%)$} & \multicolumn{3}{|c|}{ Temperature $\left({ }^{\circ} \mathrm{C}\right)$} \\
\hline & $<0$ & $0-3$ & $3-5$ & $5-10$ & $10-15$ & $15-20$ & $>20$ & Minimum & Medium & Maximum \\
\hline April & 0.0 & 0.0 & 3.7 & 33.3 & 48.1 & 14.8 & 0.0 & 4.7 & 19.0 & 33.7 \\
\hline May & 0.0 & 9.7 & 9.7 & 51.6 & 12.9 & 16.1 & 0.0 & 1.2 & 15.3 & 32.6 \\
\hline June & 0.0 & 16.6 & 33.3 & 40.0 & 6.7 & 3.3 & 0.0 & 1.7 & 12.8 & 26.8 \\
\hline July & 8.3 & 33.3 & 12.5 & 20.8 & 16.7 & 8.3 & 0.0 & -2.2 & 12.4 & 29.5 \\
\hline August & 0.0 & 0.0 & 16.1 & 67.7 & 12.9 & 3.3 & 0.0 & 4.5 & 12.7 & 27.6 \\
\hline
\end{tabular}


expressed in percentage was calculated by the equation $\mathrm{GS} \%=\left(\mathrm{GS} / \mathrm{X}_{0}\right) \times 100$, in which $\mathrm{X}_{0}$ is the overall trait mean.

\section{Results and Discussion}

A temperature of $-2.2^{\circ} \mathrm{C}$ was recorded on July 24, 2013. From April to August, minimum temperatures below $3{ }^{\circ} \mathrm{C}$ occurred on $13.6 \%$ of the days, with the possibility of frost on a total of 20 days in the five-month period of experimental temperature measurement (Table 1).

Due to these climatic conditions, the apical meristem of the plants varied from a healthy bud (Figures $1 \mathrm{~A}$ and $1 \mathrm{~F}$ ) to a necrotic bud with a lesion beneath it, covering a large part of the stalk (Figure $1 \mathrm{~B}$ ). Plants with leaves varying from straw yellow burned by frost (Figure $1 \mathrm{C}$ ) to green leaves with damaged tips only (Figures $1 \mathrm{C}$ and $1 \mathrm{E}$ ) were observed in the tested population. Moreover, plants were also observed that resumed growth after the cold events by growing new leaves from the apical meristem (Figure 1 D). Hale et al. (2016) evaluated the critical temperatures for frost damage on sugarcane, showing that a slight damage to terminal buds occurs between 0.0 and $-2.2^{\circ} \mathrm{C}$, and that apical meristem and auxiliary buds are killed between -2.8 and $-3.9^{\circ} \mathrm{C}$.

Variance components estimated for the population were significant by the deviance analysis (Table 2). For the agricultural yield-related traits (Brix, MSH and $\mathrm{MBH}$ ), both additive and dominance effects were significant. These results are similar to those of other studies, in which the populations were grown and selected in regions without cold effect (Bastos et al., 2003; Oliveira et al., 2013). This shows the high genetic variance in the population, which can be exploited and fixed by asexual reproduction in the selection process. This fact indicates the potential of selection for plants with high yield and sugar production, while also tolerant to the climatic conditions of southern Brazil.

As to the estimates of individual heritability coefficients (Table 3) in the narrow sense $\left(\mathrm{h}^{2}{ }_{\mathrm{a}}\right)$, broad sense $\left(\mathrm{h}_{\mathrm{g}}^{2}\right)$, and between means of full-sib families $\left(\mathrm{h}_{\mathrm{mf}}{ }^{2}\right)$, the highest individual heritabilities $\left(\mathrm{h}_{\mathrm{a}}^{2}\right)$ were found for leaf survival scores $(0.181 \pm 0.040)$, and for megagrams of stalks per hectare $(0.068 \pm 0.020)$. The individual heritabilities showed moderate and similar magnitude to that reported by Oliveira et al. (2008) and Silva et al. (2015), in an environment without cold stress. The heritability values observed in this study indicate a higher uncertainty in the phenotypic observations at plant than at family level. In this sense, the selection of promising families followed by selection within families may be a useful strategy for the development of genotypes.

However, the mean broad-sense heritability of families $\left(\mathrm{h}_{\mathrm{mf}}{ }_{\mathrm{m}}\right)$ increased in comparison with the other heritability coefficients, to values between 0.546 and 0.760, for NSC and SD, respectively. This confirms the advantage of using family data to select traits with low individual heritability (Kimbeng \& Cox, 2003; Resende \& Barbosa, 2006; Oliveira et al., 2013). The same authors reported that the combination of family selection followed by selection of individual clones is efficient and practical for the first stage of sugarcane selection.

The results obtained for heritability between means of full-sib families $\left(\mathrm{h}^{2} \mathrm{mf}\right)$ for the cold tolerance-related traits ABS and TLS (survival scores of apical bud and top leaves) was moderate (Table 3), indicating that, in the initial stages, the selection of superior families, associated with the selection of genotypes within these families with higher scores of apical bud survival, tend to result in higher-genetic gain, increasing the probability of identifying genotypes with higher-cold tolerance. Therefore, when using information of the parents for the selection of cold-tolerant plants, the selection accuracy increases from low to moderate. Confirming this understanding, Resende \& Barbosa (2006) and Oliveira et al. (2011) reported that the probability of selection of potential clones was greater among crosses that exceeded the parent mean.

For all traits, accuracy between families $\left(\mathrm{Ac}_{\mathrm{fam}}\right)$ was higher than 0.70 , evidencing the precision of the inferences on the genotypic means. According to Resende (2007), this parameter indicates the correlation between the predicted and true genotypic values, and in this study, the values were classified in the high-precision and median-selectivity group.

The estimates of the coefficients of phenotypic variation $\left(\mathrm{CV}_{\mathrm{ph}}\right)$ ranged from 10.9 to $85.1 \%$ for Brix and $\mathrm{MSH}$, respectively (Table 4). The coefficient of environmental variation (CVe) varied from 4.6 to $26.0 \%$ for Brix and MSH, respectively. The estimates of the coefficients of genotypic variation for the traits $\mathrm{MSH}$ and $\mathrm{MBH}$ indicated variability, showing the possibility of selection. Based on the significance of the 
additive genetic component for these traits, gains and genetic progress with selection are possible. A similar CVg value was reported by Oliveira et al. (2016) and
Silva et al. (2015) for MSH; and higher coefficients (36\%) for the traits $\mathrm{MSH}$ and $\mathrm{MBH}$ were reported by

Oliveira et al. (2013).
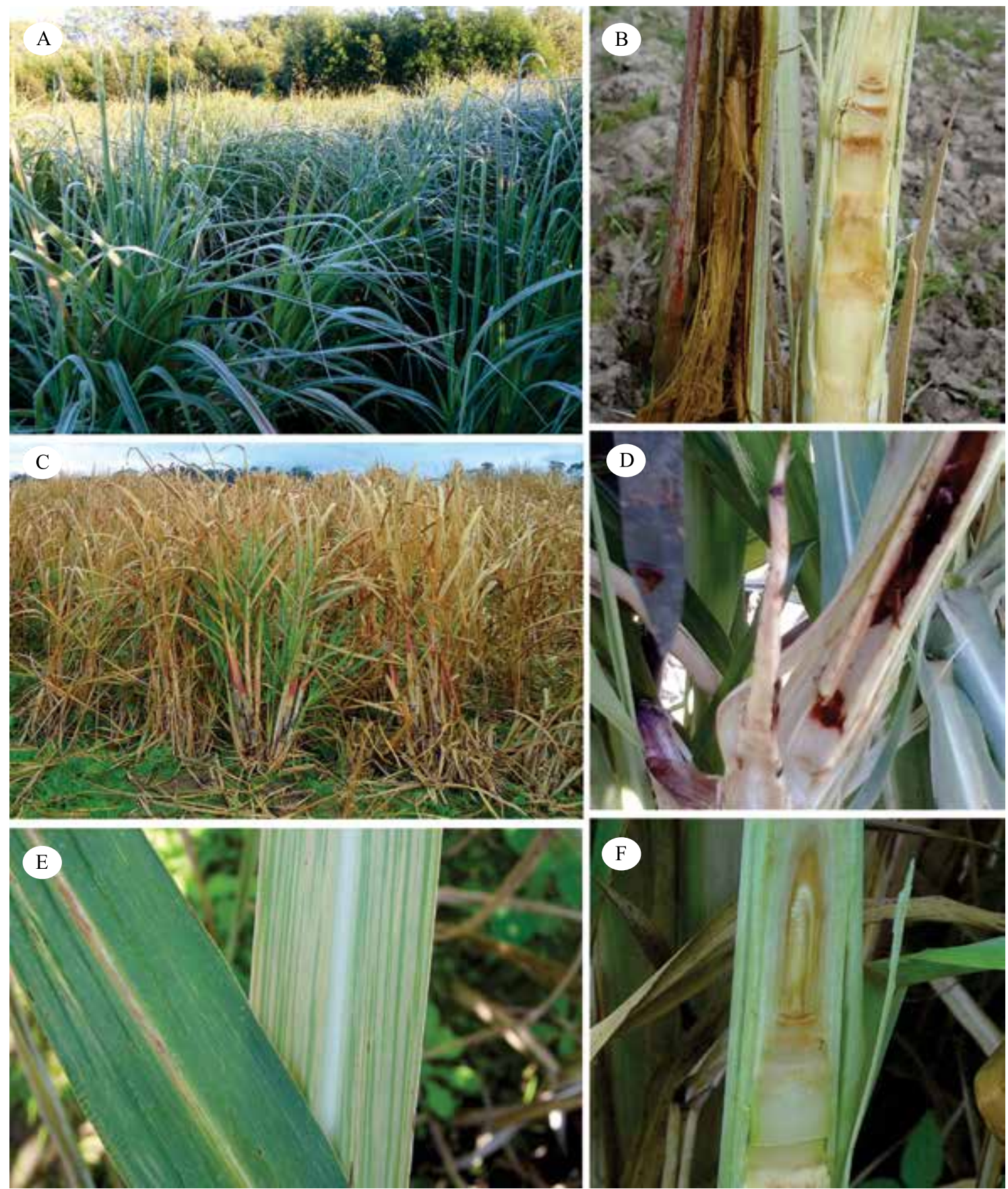

Figure 1. Frost formation on sugarcane (Saccharum spp.) leaves, on July 24, 2013, at the lowest recorded temperature $-2.2^{\circ} \mathrm{C}$ (A), apical meristem with large lesion (ABS score 1). On the left and right: live bud without lesion (ABS score 5) (B); detail of a plant (clump) with green leaves after frost (TLS score 4) (C); resumption of growth in the apical meristem (ABS score 4) (D); difference between the leaves of a genotype evaluated as TLS score 5 and a genotype with TLS score 2 (E); detail of a healthy apical bud, ABS score 5 (F). 
For the predictions of expected progress and percentage of selection gain (GS) of the studied traits, at the family level, the same selection intensity was considered for all variables under study, that is, $10 \%$ (Table 5). The highest genetic gains were estimated for the traits $\mathrm{MSH}$ and $\mathrm{MBH}$, followed by NSC, indicating high gains with selection for these traits. Gains were lower for Brix and TLS. These results were similar to those of Pedrozo et al. (2009), who found gains between 61 and $98 \%$ for $\mathrm{MBH}$, depending on the population. Likewise, with high values of heritability and genotypic variance, Oliveira et al. (2008) obtained considerable gains of up to $75 \%$ for MSH at family level. Therefore, the genetic potential was exploited in the base population evaluated under cold stress in southern Brazil, and progress was obtained with the selection for cold-tolerance in sugarcane .
The genotypic values (Vgf) and the overall mean of the evaluated traits (Table 6) represent the performance of the 53 full-sib families under cold stress. Based on the family classification for megagrams of brix per hectare (MBH), family RB867515 x RB996961 obtained the highest genotypic value (15.1), followed by CP72-2086 x RB966928, RB855156 x RB987935, RB72454 x RB965902, CP72-2086 x RB965902, and RB965902 x CP72-2086. The probability is high that these six families with high genotypic values for $\mathrm{MBH}$ contain genotypes that would produce higher yields, even under cold stress (Figure $1 \mathrm{C}$ ). In this sense, selection in families with higher genotypic values tends to be more effective for the identification of a higher proportion of promising genotypes (Silva et al., 2015; Oliveira et al., 2016). Therefore, the above

Table 2. Estimates of variance components by maximum likelihood (REML), for scores of apical bud survival (ABS) and top leaf survival (TLS) after frost, number of stalks per clump (NSC), stalk height (SH), stalk diameter (SD), total soluble solids (Brix); megagrams of stalks per hectare (MSH), and megagrams of brix per hectare (MBH), in 53 full-sib sugarcane (Saccharum spp.) families under cold stress.

\begin{tabular}{lccccccc}
\hline Trait & $\sigma_{\mathrm{a}}^{2}$ & $\sigma_{\mathrm{d}}^{2}$ & $\sigma_{\mathrm{g}}^{2}$ & $\sigma_{\text {plot }}^{2}$ & $\sigma_{\text {block }}^{2}$ & $\sigma_{\mathrm{c}}^{2}$ & $\sigma_{\mathrm{f}}^{2}$ \\
\hline ABS & 0.101 & 0.046 & 0.096 & 0.108 & 0.064 & 0.532 & 0.850 \\
TLS & 0.106 & 0.036 & 0.089 & 0.093 & 0.056 & 0.296 & 0.588 \\
\hline NSC & 0.182 & 0.426 & 0.517 & 0.461 & 0.151 & 16.519 & 17.739 \\
SH & 37.707 & 37.670 & 56.524 & 70.221 & 61.112 & 424.726 & 631.436 \\
SD & 3.890 & 0.275 & 2.220 & 1.156 & 0.244 & 16.970 & 22.535 \\
BRIX & 0.584 & 0.175 & 0.467 & 0.622 & 0.221 & 2.720 & 4.323 \\
MSH & 166.275 & 52.933 & 136.071 & 122.871 & 70.374 & 2041.361 & 2453.814 \\
MBH & 5.129 & 2.084 & 4.649 & 4.212 & 1.723 & 76.138 & 89.286 \\
\hline
\end{tabular}

Additive genetic variance $\left(\sigma_{\mathrm{a}}^{2}\right)$; genetic variance of dominance among full-sib progenies $\left(\sigma_{\mathrm{d}}^{2}\right)$; genotypic variance among progenies $\left(\sigma_{\mathrm{g}}^{2}\right)$; plot variance $\left(\sigma_{\text {plot }}^{2}\right)$; block variance $\left(\sigma_{\text {block }}^{2}\right)$; residual plot variance $\left(\sigma_{c}^{2}\right)$; and individual phenotypic variance $\left(\sigma^{2}\right)$.

Table 3. Estimates of individual heritability coefficients in the narrow sense - additive effects $\left(\mathrm{h}^{2}{ }_{\mathrm{a}}\right)$; individual heritability in the broad sense $\left(\mathrm{h}_{\mathrm{g}}^{2}\right)$ - total genotypic effects, and mean broad-sense heritability of the families $\left(\mathrm{h}^{2}{ }_{\mathrm{mf}}\right)$ of a population of 53 sugarcane (Saccharum spp.) families evaluated under cold stress for the traits score of apical bud survival (ABS) and top leaf survival (TLS) after frost, number of stalks per clump (NSC), stalk height (SH), stalk diameter (SD), total soluble solids (Brix), megagrams of stalks per hectare (MSH), and megagrams of brix per hectare (MBH).

\begin{tabular}{lccc}
\hline Trait & $\mathrm{h}^{2}$ & $\mathrm{~h}_{\mathrm{g}} \mathrm{h}_{\mathrm{mf}}$ & 0.678 \\
\hline Apical bud survival (ABS) & $0.118 \pm 0.032$ & 0.332 & 0.708 \\
Top leaf survival (TLS) after frost & $0.181 \pm 0.040$ & 0.428 & 0.546 \\
\hline Number of stalks per clump (NSC) & $0.010 \pm 0.008$ & 0.106 & 0.647 \\
Stalk height (SH) & $0.060 \pm 0.019$ & 0.298 & 0.760 \\
Stalk diameter (SD) & $0.173 \pm 0.032$ & 0.221 & 0.644 \\
Total soluble solids (Brix) & $0.135 \pm 0.029$ & 0.297 & 0.641 \\
Megagrams of stalks per hectare (MSH) & $0.068 \pm 0.020$ & 0.154 & 0.631 \\
Megagrams of brix per hectare (MBH) & $0.057 \pm 0.019$ & 0.151 & \\
\hline
\end{tabular}


families were derived from hybrid combinations which promote yield increase.

Similarly, based on the traits bud and leaf survival scores (ABS and TLS) that indicate cold-tolerance, the family CP72-2086 x RB966928 stood out with a genotypic value of 3.8 (ABS) and 4.6 (TLS). It is worth mentioning that this family had the second highest genotypic values for $\mathrm{MSH}$ and $\mathrm{MBH}$, and the highest ones for ABS and TLS. These advantages can explain that the cross from which the highest number of clones was selected for the second selection phase was family CP72-2086 x RB966928. Therefore, in general terms, this family comprised the highest quantity and quality of plants combining cold-tolerance and favorable yield traits, indicating the possibility of selecting a greater number of promising clones from it. It is noteworthy that for BRIX, this family ranked $5^{\text {th }}$, with a genotypic value (Vgf) of 20.0.

The families TUC77-42 x RB966928, NA56-79 x RB867515, RB966928 x CP72-2086, RB987935 x RB867515, CP72-2086 x RB965902, and RB867515 $x$ RB996961 were also evaluated with the highest mean scores for ABS and TLS. This indicates that these families have a greater number for cold- and frost-tolerant plants, since the survival of these structures was higher, even after temperature drops to below $-2.2^{\circ} \mathrm{C}$. It is worth noting that the parents RB966928, CP72-2086, and RB867515 participated most frequently in the crosses with highest coldtolerance scores. Two of the three parents, RB966928 and CP72-2086, are cultivars selected in cold-stressed environments - state of Paraná, Brazil, and Canal

Table 4. Estimates of the coefficients of phenotypic $\left(\mathrm{CV}_{\mathrm{ph}}\right)$, genetic $(\mathrm{CVg})$, environmental $(\mathrm{CVe})$, and relative variations $(\mathrm{CVr})$, and selective accuracy among families $\left(\mathrm{Ac}_{\mathrm{fam}}\right)$ for the traits scores of apical bud (ABS) and leaf (TLS) after frost, number of stalks per clump (NSC), stalk height (SH), stalk diameter (SD), total soluble solids (Brix), megagrams of stalks per hectare (MSH), and megagrams of brix per hectare (MBH), in 53 full-sib sugarcane (Saccharum spp.) families under cold stress.

\begin{tabular}{|c|c|c|c|c|c|}
\hline Trait & $\mathrm{CV}_{\mathrm{ph}}(\%)$ & CVg (\%) & CVe (\%) & $\mathrm{CVr}$ & $A c_{\text {fam }}$ \\
\hline ABS & 26.62 & 8.93 & 10.67 & 0.84 & 0.82 \\
\hline TLS & 18.36 & 7.16 & 7.96 & 0.90 & 0.84 \\
\hline NSC & 56.81 & 9.70 & 15.33 & 0.63 & 0.74 \\
\hline $\mathrm{SH}$ & 27.31 & 8.17 & 10.45 & 0.78 & 0.80 \\
\hline SD & 18.96 & 5.95 & 5.79 & 1.03 & 0.87 \\
\hline BRIX & 10.90 & 3.58 & 4.61 & 0.78 & 0.80 \\
\hline MSH & 85.15 & 20.05 & 26.02 & 0.77 & 0.80 \\
\hline MBH & 83.82 & 19.13 & 25.32 & 0.76 & 0.79 \\
\hline
\end{tabular}

Table 5. Expected progress and percentages of genetic gain (GS) for the traits score of apical bud survival (ABS) and top leaf survival (TLS) after frost, number of stalks per clump (NSC), stalk height (SH), stalk diameter (SD), total soluble solids (Brix), megagrams of stalks per hectare (MSH), and megagrams of brix per hectare (MBH), in 53 full-sib sugarcane (Saccharum spp.) families under cold stress.

\begin{tabular}{|c|c|c|c|c|c|c|}
\hline Trait & $\mathrm{X}_{0}$ & $\mathrm{Xs}$ & DS & $\mathrm{h}_{\mathrm{mf}}^{2}$ & GS & GS (\%) \\
\hline $\mathrm{ABS}$ & 3.46 & 4.84 & 1.38 & 0.68 & 0.93 & 26.92 \\
\hline TLS & 4.18 & 4.95 & 0.77 & 0.71 & 0.55 & 13.11 \\
\hline $\mathrm{NSC}$ & 7.41 & 14.66 & 7.24 & 0.55 & 3.95 & 53.32 \\
\hline $\mathrm{SH}$ & 92.01 & 135.23 & 43.22 & 0.65 & 27.98 & 30.41 \\
\hline SD & 25.03 & 33.20 & 8.16 & 0.76 & 6.21 & 24.79 \\
\hline BRIX & 19.07 & 22.64 & 3.58 & 0.64 & 2.30 & 12.09 \\
\hline MSH & 58.17 & 143.38 & 85.20 & 0.64 & 54.57 & 93.81 \\
\hline MBH & 11.27 & 27.53 & 16.25 & 0.63 & 10.26 & 91.01 \\
\hline
\end{tabular}

$\mathrm{X}_{0}$, overall mean; $\mathrm{X}_{\mathrm{S}}$, mean of the selected population at $10 \%$ selection pressure; $\mathrm{X}_{\mathrm{S}}-\mathrm{X}_{0}(\mathrm{DS})$, selection differential; heritability coefficient between means of full-sib families $\left(\mathrm{h}^{2}{ }_{\mathrm{mf}}\right)$; GS, expected genetic gains by selection; GS (\%) genetic gain in percentage. 
Table 6. Genotypic value (Vgf) and general mean in 53 full-sib sugarcane (Saccharum spp.) families under cold stress for the traits score of apical bud survival (ABS) and top leaf survival (TLS) after frost, number of stalks per clump (NSC), stalk height $(\mathrm{SH})$, stalk diameter (SD), total soluble solids (BRIX), megagrams of stalks per hectare (MSH), and megagrams of brix per hectare $(\mathrm{MBH})$.

\begin{tabular}{|c|c|c|c|c|c|c|c|c|}
\hline Family & $\mathrm{ABS}$ & TLS & $\mathrm{NCM}$ & $\mathrm{SH}$ & SD & BRIX & MSH & $\mathrm{MBH}^{(1)}$ \\
\hline RB867515 x RB996961 & 3.6 & 4.3 & 8.7 & 97.8 & 27.2 & 18.2 & 82.1 & 15.1 \\
\hline CP72-2086 x RB966928 & 3.8 & 4.6 & 8.0 & 103.0 & 26.8 & 20.0 & 71.4 & 14.3 \\
\hline RB855156 x RB987935 & 3.5 & 4.3 & 8.2 & 90.8 & 26.0 & 19.6 & 69.2 & 13.9 \\
\hline RB72454 x RB965902 & 3.5 & 4.1 & 8.2 & 93.1 & 26.5 & 19.0 & 70.0 & 13.4 \\
\hline CP72-2086 x RB965902 & 3.6 & 4.3 & 7.5 & 89.1 & 27.1 & 19.6 & 67.0 & 13.4 \\
\hline RB965902 x CP72-2086 & 3.5 & 4.3 & 8.0 & 92.5 & 26.8 & 19.6 & 68.3 & 13.3 \\
\hline RB867515 x RB987935 & 3.5 & 4.3 & 7.3 & 100.8 & 27.4 & 18.0 & 71.0 & 12.9 \\
\hline RB987935 x RB867515 & 3.7 & 4.3 & 7.6 & 99.7 & 27.1 & 18.2 & 70.5 & 12.9 \\
\hline RB867515 x RB946903 & 3.2 & 3.9 & 7.5 & 104.5 & 26.1 & 18.1 & 70.1 & 12.8 \\
\hline RB966928 x RB996961 & 3.6 & 4.4 & 7.1 & 93.2 & 26.5 & 20.0 & 64.0 & 12.7 \\
\hline NA56-79 x RB867515 & 3.8 & 4.5 & 7.5 & 109.7 & 26.1 & 18.1 & 68.7 & 12.6 \\
\hline RB966928 x CP72-2086 & 3.7 & 4.5 & 7.5 & 95.3 & 26.4 & 20.0 & 63.3 & 12.6 \\
\hline RB011681 x RB72454 & 3.5 & 4.3 & 7.7 & 90.1 & 25.9 & 19.6 & 62.9 & 12.6 \\
\hline RB966928 x RB987935 & 3.5 & 4.4 & 7.5 & 95.8 & 26.2 & 19.3 & 64.7 & 12.6 \\
\hline RB987935 x RB975932 & 3.6 & 4.0 & 7.6 & 101.2 & 25.6 & 18.8 & 65.7 & 12.5 \\
\hline RB867515 x RB966928 & 3.5 & 4.4 & 7.2 & 97.8 & 26.4 & 19.1 & 64.3 & 12.4 \\
\hline RB966229 x RB996961 & 3.7 & 4.3 & 8.0 & 93.2 & 24.5 & 18.7 & 64.5 & 12.3 \\
\hline RB996963 x RB996961 & 3.6 & 4.3 & 7.6 & 90.6 & 25.9 & 19.4 & 62.1 & 12.1 \\
\hline RB966928 x RB855589 & 3.6 & 4.3 & 7.0 & 93.1 & 25.9 & 19.7 & 60.1 & 12.0 \\
\hline RB966928 x RB867515 & 3.5 & 4.3 & 7.3 & 92.6 & 26.3 & 19.3 & 62.1 & 12.0 \\
\hline TUC77-42 x RB966928 & 3.8 & 4.5 & 8.0 & 93.5 & 24.7 & 20.0 & 58.6 & 11.7 \\
\hline RB987935 x RB966928 & 3.4 & 4.3 & 7.0 & 95.5 & 26.1 & 19.3 & 59.8 & 11.6 \\
\hline RB946903 x RB987935 & 3.2 & 3.7 & 7.4 & 94.9 & 25.6 & 18.5 & 60.1 & 11.4 \\
\hline RB966229 x RB975932 & 3.6 & 4.3 & 8.2 & 99.5 & 23.1 & 18.9 & 59.1 & 11.4 \\
\hline RB72454 x RB011681 & 3.3 & 3.8 & 7.6 & 87.5 & 25.5 & 18.9 & 58.1 & 11.3 \\
\hline RB867515 x RB965518 & 3.7 & 4.4 & 7.7 & 97.7 & 25.5 & 18.3 & 61.4 & 11.2 \\
\hline RB855589 x RB966928 & 3.5 & 4.3 & 7.2 & 97.8 & 25.3 & 19.2 & 57.6 & 11.2 \\
\hline RB855156 x RB946903 & 3.3 & 4.0 & 8.0 & 92.3 & 23.8 & 19.3 & 57.1 & 11.2 \\
\hline RB867515 x NA56-79 & 3.5 & 4.2 & 7.5 & 95.7 & 25.1 & 18.0 & 60.7 & 11.0 \\
\hline RB996963 x RB966229 & 3.5 & 4.2 & 7.7 & 91.3 & 23.4 & 18.8 & 55.6 & 11.0 \\
\hline RB975932 x RB966928 & 3.7 & 4.3 & 7.9 & 95.9 & 24.3 & 19.2 & 55.9 & 11.0 \\
\hline RB987935 x RB855156 & 3.4 & 4.2 & 7.6 & 88.1 & 25.6 & 18.5 & 58.0 & 10.8 \\
\hline RB946903 x RB867515 & 3.0 & 3.8 & 6.7 & 98.8 & 25.5 & 18.3 & 58.3 & 10.8 \\
\hline RB965518 x RB966928 & 3.4 & 4.4 & 7.2 & 93.2 & 24.0 & 19.7 & 52.9 & 10.7 \\
\hline RB966928 x RB965518 & 3.5 & 4.5 & 7.5 & 88.2 & 24.1 & 19.4 & 53.1 & 10.5 \\
\hline RB965518 x RB011681 & 3.3 & 4.3 & 7.5 & 87.4 & 24.1 & 19.3 & 53.2 & 10.5 \\
\hline NA56-79 x RB72454 & 3.4 & 4.1 & 6.4 & 91.3 & 25.2 & 19.0 & 54.0 & 10.5 \\
\hline NA56-79 x RB855156 & 3.5 & 4.4 & 7.1 & 95.3 & 24.1 & 19.3 & 53.2 & 10.4 \\
\hline RB966928 x RB975932 & 3.5 & 4.3 & 7.1 & 94.3 & 24.4 & 19.3 & 53.7 & 10.4 \\
\hline RB996963 x RB966928 & 3.6 & 4.4 & 7.0 & 83.0 & 24.4 & 19.6 & 49.7 & 10.2 \\
\hline RB966928 x RB996963 & 3.5 & 4.4 & 7.0 & 88.2 & 24.9 & 19.7 & 52.1 & 10.2 \\
\hline RB987935 x RB946903 & 2.7 & 3.6 & 6.3 & 92.0 & 25.7 & 18.2 & 54.7 & 10.2 \\
\hline RB996963 x RB946903 & 3.2 & 4.0 & 7.5 & 92.1 & 24.0 & 19.0 & 52.1 & 10.2 \\
\hline RB966928 x TUC77-42 & 3.5 & 4.4 & 6.7 & 86.0 & 24.8 & 20.0 & 50.5 & 10.1 \\
\hline RB72454 x NA56-79 & 3.4 & 4.0 & 6.6 & 84.5 & 25.3 & 18.5 & 51.1 & 9.8 \\
\hline RB867515 x CP70-321 & 3.5 & 4.1 & 6.9 & 89.8 & 25.1 & 18.4 & 50.9 & 9.6 \\
\hline CP70-321 x RB867515 & 3.4 & 4.1 & 6.9 & 89.4 & 24.9 & 18.9 & 49.5 & 9.4 \\
\hline RB855156 x NA56-79 & 3.6 & 4.3 & 6.8 & 84.2 & 24.0 & 19.8 & 45.7 & 9.1 \\
\hline RB946903 x RB996963 & 2.7 & 3.5 & 7.2 & 81.9 & 23.6 & 18.7 & 45.9 & 9.1 \\
\hline RB946903 x RB855156 & 2.8 & 3.5 & 6.9 & 82.2 & 23.4 & 19.2 & 45.0 & 8.8 \\
\hline RB966229 x RB996963 & 3.5 & 4.2 & 6.9 & 84.1 & 22.9 & 18.4 & 45.5 & 8.6 \\
\hline RB966229 x NA56-79 & 3.6 & 4.2 & 7.3 & 88.6 & 22.5 & 18.3 & 45.0 & 8.5 \\
\hline RB946903 x NA56-79 & 3.0 & 3.7 & 6.4 & 87.3 & 23.6 & 18.3 & 44.2 & 8.3 \\
\hline Overall mean & 3.5 & 4.2 & 7.4 & 92.0 & 25.0 & 19.1 & 58.2 & 11.3 \\
\hline
\end{tabular}

${ }^{(1)}$ Families classified for the trait megagrams of brix per hectare (MBH). 
Point, Florida, USA, respectively (Daros et al., 2010; Hale et al., 2016).

For the quality trait BRIX, the highest $\operatorname{Vgf}(\geq 20.0)$ were found for the families RB966928 x CP72-2086, CP72-2086 x RB966928, RB966928 x RB996961, RB966928 x TUC77-42, and TUC77-42 x RB966928. These families are better suited for selection for earliness, since the Brix content was measured nine months after planting, at an early stage. In all very early crosses, the early cultivar RB966928 was noted as parent, emphasizing the positive effect of this parent for Brix value increases in juice, that is, with higher-sucrose production at the beginning of harvest (Daros et al., 2010). The results of using this parent for BRIX in crosses with the cultivars CP72-2086 (USA), TUC77-42 (Argentina), and RB996961 (Brazil) were superior to the other parents.

\section{Conclusions}

1. In the base population of sugarcane families, variability and heritability within families are high, with the possibility of selecting cold-tolerant genotypes within the best families.

2. The best sugarcane families are RB966928 x CP72-2086, CP72-2086 x RB966928, RB966928 x RB996961, RB966928 x TUC77-42, and TUC77-42 x RB966928.

3. Selection based on the apical survival index and leaf survival index associated with yield traits is a promising method for sugarcane breeding in southern Brazil.

\section{Acknowledgments}

To Coordenação de Aperfeiçoamento de Pessoal de Nível Superior (Capes), for granting a scholarship; and to Conselho Nacional de Desenvolvimento Científico e Tecnológico (CNPq, Protocol No. 486851/2013-3) and Financiadora de Estudos e Projetos (Finep), for funding this project.

\section{References}

ACOMPANHAMENTO DA SAFRA BRASILEIRA [DE] CANA-DE-AÇÚCAR: safra 2016/17: primeiro levantamento, v.3, n.1, abr. 2016. Available at: <http://www.conab.gov.br/ OlalaCMS/uploads/arquivos/16_04_18_14_27_15_boletim_ cana_portugues_-_1o_lev_-_16.pdf $>$.Accessed on: May 102017.
ATKIN, F.C.; DIETERS, M.J.; STRINGER, J.K. Impact of depth of pedigree and inclusion of historical data on the estimation of additive variance and breeding values in a sugarcane breeding program. Theoretical and Applied Genetics, v.119, p.555-565, 2009. DOI: $10.1007 / \mathrm{s} 00122-009-1065-7$.

BARBOSA, M.H.P.; RESENDE, M.D.V. de; BRESSIANI, J.A.; SILVEIRA, L.C.I. da; PETERNELLI, L.A. Selection of sugarcane families and parents by REML/BLUP. Crop Breeding and Applied Biotechnology, v.5, p.443-450, 2005. DOI: 10.12702/1984-7033.v05n04a10.

BASTOS I.T.; BARBOSA M.H.P.; CRUZ, C.D.; BURNQUIST, W.L.; BRESSIANI, J.A.; SILVA, F.L. da. Análise dialélica em clones de cana-de-açúcar. Bragantia, v.62, p.199-206, 2003. DOI: 10.1590/S0006-87052003000200004.

CESNIK, R.; BASSINELLO, A.I.; OLIVEIRA, F.F.S. Frost resistance of sugarcane clones and varieties: a study of some progenies. In: INTERNATIONAL SOCIETY OF SUGAR CANE TECHNOLOGISTS CONGRESS, 16., 1977, São Paulo. Proceedings. São Paulo: Companhia Brasileira de Impressão e Propaganda, 1978. v.1 p.305-313.

DAROS, E.; BESPALHOK FILHO, J.C.; ZAMBON, J.L.C.; IDO, O.T.; OLIVEIRA, R.A. de; RUARO, L.; WEBER, H. RB966928 Early maturing sugarcane cultivar. Crop Breeding and Applied Biotechnology, v.10, p.278-281, 2010. DOI: 10.1590/S198470332010000300016.

EDMÉ, S.J.; GLAZ, B.S. Field response of sugarcane genotypes to freeze stress with genotype $\mathrm{x}$ environment effects on quality traits. Journal of Crop Improvement, v.27, p.1-30, 2013. DOI: 10.1080/15427528.2012.720653.

FAO. Food and Agriculture Organization of the United Nations. Faostat: Food and agriculture data. 2017. Available at: <http:// www.fao.org/faostat/en/>. Accessed on: May 162017.

FRIESEN, P.C.; PEIXOTO, M.M.; BUSCH, F.A.; JOHNSON, D.C.; SAGE, R.F. Chilling and frost tolerance in Miscanthus and Saccharum genotypes bred for cool temperate climates. Journal of Experimental Botany, v.65, p.3749-3758, 2014. DOI: 10.1093/ jxb/eru105.

HALE, A.L.; VIATOR, R.P.; EGGLESTON, G.; HODNETT, G.; STELLY, D.M.; BOYKIN, D.; MILLER, D.K. Estimating broad sense heritability and investigating the mechanism of genetic transmission of cold tolerance using mannitol as a measure of post-freeze juice degradation in sugarcane and energycane (Saccharum spp.). Journal of Agricultural and Food Chemistry, v.64, p.1657-1663, 2016. DOI: 10.1021/acs.jafc.5b03803.

KIMBENG, C.A.; COX, M.C. Early generation selection of sugarcane families and clones in Australia: a review. Journal of the American Society of Sugarcane Technologists, v.23, p.2039, 2003.

LANDELL, M.G. de A.; SILVA, M. de A. As estratégias de seleção da cana em desenvolvimento no Brasil. Visão Agrícola, v.1, p.18-23, 2004.

LEGENDRE, B.L.; TEW, T.; BIRKETT, H.; EGGLESTON, G.; FINGER, C.; STEIN, J. Impact of subfreezing temperatures on the 2006 Louisiana sugarcane harvest. Sugar Journal, v.70, p.2728, 2007.

Pesq. agropec. bras., Brasília, v.53, n.5, p.583-592, May 2018 DOI: $10.1590 / \mathrm{S} 0100-204 \mathrm{X} 2018000500007$ 
OLIVEIRA, R.A. de; DAROS, E.; RESENDE, M.D.V. de; BESPALHOK-FILHO, J.C.; ZAMBON, J.L.C.; SOUZA, T.R. de; LUCIUS, A.S.F. Procedimento Blupis e seleção massal em cana-de-açúcar. Bragantia, v.70, p.796-800, 2011. DOI: 10.1590/ S0006-87052011000400010.

OLIVEIRA, R.A. de; DAROS, E; BESPALHOK FILHO, J.C.; ZAMBON, J.L.C.; IDO, O.T.; WEBER, H.; RESENDE, M.D.V. de; ZENI NETO, H. Seleção de famílias de cana-de-açúcar via modelos mistos. Scientia Agraria, v.9, p.269-274, 2008. DOI: 10.5380/rsa.v9i3.11564.

OLIVEIRA, R.A.; DAROS, E.; RESENDE, M.D.V.; BESPALHOK FILHO, J.C.; ZAMBON, J.L.C.; RUARO, L. Early selection in sugarcane family trials via BLUP and BLUPIS procedures. Acta Scientiarum. Agronomy, v.35, p.427-434, 2013. DOI: 10.4025/ actasciagron.v35i4.16430.

OLIVEIRA, R.A.; LUCIUS, A.S.F.; DAROS, E.; BESPALHOKFILHO, J.C.; ZAMBON, J.L.C.; WEBER, H.; VERISSIMO, M.A.A. Performance of sugarcane families at different stages of a selection program. International Sugar Journal, v.16, p.378381, 2016.

PEDROZO, C.A.; BENITES, F.R.G.; BARBOSA, M.H.P.; RESENDE, M.D.V. de; SILVA, F.L. da. Eficiência de índices de seleção utilizando a metodologia REML/BLUP no melhoramento da cana-de-açúcar. Scientia Agraria, v.10, p.31-36, 2009. DOI: 10.5380/rsa.v10i1.11711.

RESENDE, M.D.V. de. Selegen - Reml/Blup: sistema estatístico e seleção genética computadorizada via modelos lineares mistos. Colombo: Embrapa Florestas, 2007. 359p.

RESENDE, M.D.V. de. Software Selegen-REML/BLUP: a useful tool for plant breeding. Crop Breeding and Applied Biotechnology, v.16, p.330-339, 2016. DOI: 10.1590/1984-70332016v16n4a49.
RESENDE, M.D.V. de; BARBOSA, M.H.P. Selection via simulated individual BLUP based on family genotypic effects in sugarcane. Pesquisa Agropecuária Brasileira, v.41, p.421-429, 2006. DOI: 10.1590/S0100-204X2006000300008.

SANTOS, H.G. dos; JACOMINE, P.K.T.; ANJOS, L.H.C. dos; OLIVEIRA, V.A. de; LUMBRERAS, J.F.; COELHO, M.R.; ALMEIDA, J.A. de; CUNHA, T.J.F.; OLIVEIRA, J.B. de. Sistema brasileiro de classificação de solos. 3.ed. rev. e ampl. Brasília: Embrapa, 2013. 353p.

SILVA, F.L. da; BARBOSA, M.H.P.; RESENDE, M.D.V. de; PETERNELLI, L.A.; PEDROZO, C.A. Efficiency of selection within sugarcane families via simulated individual BLUP. Crop Breeding and Applied Biotechnology, v.15, p.1-9, 2015. DOI: 10.1590/1984-70332015v15n1a1.

SILVA, J.A. da. The importance of the wild cane Saccharum spontaneum for bioenergy genetic breeding. Sugar Tech, v.1, p.229-240, 2017. DOI: 10.1007/s12355-017-0510-1.

STRINGER, J.K.; COX, M.C.; ATKIN, F.C.; WEI, X.; HOGARTH, D.M. Family selection improves the efficiency and effectiveness of selecting original seedlings and parents. Sugar Tech, v.13, p.36-41, 2011. DOI: 10.1007/s12355-011-0073-5.

SUN. B.; LIU, G.-L.; PHAN, T.T.; YANG, L.-T.; LI, Y.-R.; XING, Y.X. Effects of cold stress on root growth and physiological metabolisms in seedlings of different sugarcane varieties. Sugar Tech, v.19, p.165-175, 2017. DOI: 10.1007/s12355-016-0452-z.

VANHEERDEN, P.D.R.; VAN ANTWERPEN, T.; RAMBURAN, S.; REDSHAW, K.A.; SNYMAN, S.J.; WEBSTER, T.M.; BERRY, S.D.; MAHER, G.W; RUTHERFORD, R.S. Rapid bulking and testing of cold tolerant varieties imported from Louisiana. Proceedings of the South African Sugar Technologists Association, v.82, p.422-426, 2009.

ZAMBON, J.L.C.; DAROS, E. Manual de experimentação para a condução de experimentos. Curitiba: UFPR, 2009. 54p.

Received on January 31, 2017 and accepted on August 10, 2017

Pesq. agropec. bras., Brasília, v.53, n.5, p.583-592, May 2018

DOI: 10.1590/S0100-204X2018000500007 